\title{
Indeks Ukuran Tubuh, Lingkar Skrotum dan Panjang Tanduk Kambing Boerka dengan Pakan Imbangan Energi- Protein Berbeda
}

\section{(Body Size Index, Scrotal Circumference and Horn Length of Boerka Goats with Different Energy-Protein Balance)}

\author{
Solehudin, Hutasoit R, Simanihuruk K, Elieser S, Ginting SP \\ Loka Penelitian Kambing Potong, PO Box 1 Galang, Sei Putih \\ solehudintaher02@gmail.com
}

\begin{abstract}
Animal performances could be determined not only by body weight but also by investigating body measurements. This study was aimed to determine the range of the Body Size Index (BSI), scrotal circumference and horn size of boerka goat fed with balancing of different energy-protein. Thirty-six of boerka goats aged 5 month was used. Completely Randomized Design (CRD) was used with six different energy-protein balance feed treatments: $\mathrm{P}_{1}(63.10 \% \mathrm{TDN} ; 13.00 \% \mathrm{CP}), \mathrm{P}_{2}(62.69 \% \mathrm{TDN} ; 15 \% \mathrm{CP}), \mathrm{P}_{3}(65.00 \% \mathrm{TDN}$; $13.00 \% \mathrm{CP}), \mathrm{P}_{4}(65.00 \% \mathrm{TDN} ; 15.00 \% \mathrm{CP}), \mathrm{P}_{5}(70.00 \% \mathrm{TDN} ; 13.00 \% \mathrm{CP})$ dan $\mathrm{P}_{6}(70.00 \%$ TDN; $15.00 \% \mathrm{CP}$ ). Data were analyzed by one-way analysis of variance (ANOVA) and continued with Duncan's multiple distance test if there were differences. The results showed significant effect $(\mathrm{P}<0.05)$ for body length but did not have significant effect $(\mathrm{P}>0.05)$ on chest circumference, scrotal circumference, horn length and BSI. The best BSI value was obtained from feeding with a TDN $62.69 \%$ and protein $15.00 \%$. BSI had correlation with scrotal circumference but not with horn length.
\end{abstract}

Key words: Body Size Index (BSI), scrotal circumference, horn length, boerka, energyprotein balance

\begin{abstract}
ABSTRAK
Performans ternak tidak hanya dapat ditentukan dengan bobot badan tetapi juga dengan melihat ukuran-ukuran tubuh. Penelitian ini bertujuan untuk mengetahui kisaran nilai Indeks Ukuran Tubuh (IUT), lingkar skrotum dan panjang tanduk kambing Boerka yang diberi pakan dengan imbangan energi protein berbeda. Ternak yang digunakan dalam dalam penelitian ini adalah kambing boerka jantan umur 5 bulan sebanyak 36 ekor. Penelitian ini menggunakan Rancangan Acak Lengkap (RAL) dengan enam perlakuan pakan imbangan energi-protein berbeda yaitu: $\mathrm{P}_{1}(63,10 \%$ TDN; $13,00 \% \mathrm{PK}), \mathrm{P}_{2}(62,69 \%$ TDN; $15,00 \% \mathrm{PK}), \mathrm{P}_{3}(65,00 \%$ TDN; $13,00 \% \mathrm{PK}), \mathrm{P}_{4}(65,00 \%$ TDN; $15,00 \% \mathrm{PK}), \mathrm{P}_{5}(70,00 \% \mathrm{TDN} ; 13,00 \% \mathrm{PK})$ dan $\mathrm{P}_{6}$ $(70,00 \%$ TDN; $15,00 \%$ PK). Data dianalisis dengan analysis of Variance (ANOVA) satu arah dan dilanjutkan dengan uji jarak berganda Duncan jika terdapat perbedaan. Hasil penelitian menunjukkan pemberian pakan memberikan pengaruh yang nyata $(\mathrm{P}<0,05)$ untuk ukuran panjang badan tetapi tidak memberikan pengaruh yang nyata $(\mathrm{P}>0,05)$ terhadap lingkar dada, lingkar skrotum, panjang tanduk dan IUT. Ukuran nilai IUT terbaik diperoleh pada pemberian pakan dengan imbangan TDN 62,69\% dan protein 15,00\%. IUT berkorelasi dengan lingkar skrotum tetapi tidak mempunyai korelasi dengan panjang tanduk.
\end{abstract}

Kata kunci: Indeks Ukuran Tubuh (IUT), lingkar skrotum, panjang tanduk, boerka, imbangan energi-protein 


\section{PENDAHULUAN}

Kambing boerka merupakan kambing hasil persilangan antara kambing jantan boer dan kambing betina lokal dari Indonesia yaitu kambing kacang. Keunggulan kambing boer adalah mempunyai postur tubuh yang besar dengan pertumbuhan yang cepat (Malan 2000). Sedangkan kambing kacang memiliki keunggulan adaptif terhadap lingkungan dan cocok untuk dikembangkan di Indonesia serta memiliki kemampuan prolifikasi yang tinggi (Romjali et al. 2002) sehingga mudah untuk dikembangbiakkan. Dengan demikian, keunggulan-keunggulan tersebut terdapat pada kambing Boerka yang merupakan hasil persilangannya.

Keunggulan yang diperoleh tentunya dipengaruhi juga oleh pakan. Pakan yang diberikan pada ternak akan berpengaruh terhadap performans ternak tersebut antara lain bobot badan, pertumbuhan dan kemampuan reproduksi. Kualitas pakan yang baik akan menghasilkan performans ternak yang baik pula. Kandungan nutrisi pakan harus memenuhi kebutuhan yang diperlukan agar produksinya optimal. Imbangan kandungan energi dan protein dalam pakan sangat berpengaruh terhadap performans produksi kambing boerka fase pertumbuhan sebagai ternak yang digunakan dalam penggemukan untuk menghasilkan capaian bobot badan yang maksimal.

Performans kambing boerka dapat ditentukan dengan melihat ukuran-ukuran tubuh. Lingkar dada dan panjang badan merupakan penduga bobot badan terbaik jika menggunakan dua peubah (Zurahmah \& The 2011). Lingkar dada dan panjang badan dapat digunakan untuk menentukan Indeks Ukuran Tubuh (IUT) ternak. Semakin besar nilai IUT menunjukkan kondisi ternak semakin gemuk. Lingkar dada dan panjang badan mempunyai korelasi yang erat dengan bobot badan (Niam 2012). Performans kambing juga bisa dilihat dari panjang tanduk yang tumbuh sepasang di kepala. Panjang tanduk kambing jantan lebih besar daripada kambing betina. Tanduk digunakan sebagai alat untuk mengalahkan ternak lainnya dalam mendapatkan makanan atau mengawini induk. Pertumbuhan tanduk dipengaruhi oleh 2 faktor yaitu faktor intrinsik dan faktor ektrinsik. Faktor intrinsik antara lain status genetik dan reproduksi. Sedangkan faktor ektrinsik antara keadaan geografi lingkungan dan pakan yang dikonsumsi (Steeve et al. 1998). Dengan demikian, pemberian pakan dengan imbangan energi-protein berbeda diperkirakan dapat mempengaruhi pertumbuhan tanduk.

Selain itu, performans reproduksi kambing jantan bisa dilihat lingkar skrotum. Hasil penelitian Bintara (2009) menyatakan bahwa lingkar skrotum berkorelasi sangat nyata dengan volume sperma. Ukuran lingkar skrotum dipengaruhi oleh tingkat pemberian pakan, umur, berat badan dan tinggi badan (Bourdon \& Brinks 1986). Lebih lanjut lagi Kaithoab et al. (1998) menyatakan bahwa pada kambing ukuran lingkar skrotum memiliki hubungan yang sangat kuat dengan berat badan. Jika berat badan dipengaruhi oleh nutrisi pakan, maka ukuran lingkar skrotum pun dapat dipastikan oleh pakan. Pemberian imbangan energi-protein pada pakan berpengaruh pada berat badan. Yustendi et al. (2013) melaporkan bahwa ukuran lingkar skrotum Kambing PE umur 18-24 bulan adalah $20-25 \mathrm{~cm}$.

Tujuan penelitian ini adalah untuk mengetahui pengaruh pemberian pakan dengan imbangan energi-protein yang berbeda terhadap IUT, lingkar skrotum dan panjang tanduk. Oleh karena minimnya informasi tentang pengaruh pemberian pakan terhadap ukuran-ukuran tubuh tertentu, sehingga perlu dilakukan penelitian kambing Boerka fase pertumbuhan. 


\section{MATERI DAN METODE}

\section{Pelaksanaan penelitian}

Penelitian dilaksanakan mulai bulan Mei 2018 di Kandang Percobaan Loka Penelitian Kambing Potong Sei Putih. Sebelum penelitian dilaksanakan, terlebih dahulu dilakukan adaptasi pemberian pakan selama 3 minggu untuk memperkenalkan dan membiasakan pakan perlakuan kepada ternak. Selanjutnya adalah perlakuan dan pengambilan data selama 6 bulan dengan melakukan pengukuran terhadap parameter tertentu.

\section{Ternak percobaan}

Ternak yang digunakan dalam penelitian ini adalah kambing boerka jantan sebanyak 36 ekor berumur seragam yaitu 5 bulan yang diambil berdasarkan data kelahiran ternak. Rata-rata bobot badan ternak adalah 11,2 $\pm 1,33 \mathrm{~kg}$. Ternak dibagi ke dalam 6 perlakuan sehingga setiap perlakuan terdiri dari 6 ekor kambing jantan boerka.

\section{Kandang}

Penelitian ini menggunakan kandang individu berukuran (1 x $0,5 \times 0,8) \mathrm{m}$ yang dilengkapi dengan bak pakan dan ember untuk tempat minum. Dinding kandang dan bak pakan terbuat dari kayu papan sedangkan alas kandang terbuat dari besi berdiameter $7 \mathrm{~cm}$ dengan jarak rapatan $1 \mathrm{~cm}$ yang memudahkan kotoran langsung jatuh ke lantai. Tinggi kandang dari lantai ke alas kandang adalah $0,5 \mathrm{~m}$ sehingga memudahkan dalam membersihkan kotoran ternak.

\section{Pakan}

Pakan yang diberikan selama penelitian adalah pakan komplit berbentuk konsentrat dengan kandungan energi protein yang berbeda. Bahan penyusun penyusun konsentrat terdiri dari bungkil inti sawit, tepung kedelai, Destillers Dried Grains with Solubles (DDGS), onggok, gaplek, molases, daun indigofera dan pelepah sawit. Konsentrat dan air minum diberikan secara ad libitum. Pakan terdiri dari enam perlakuan dengan imbangan energi-protein berbeda: pakan dengan kandungan energi $63,10 \%$ dan protein $13,00 \%\left(\mathrm{P}_{1}\right)$; pakan dengan kandungan energi $62,69 \%$ dan protein $15,00 \%\left(\mathrm{P}_{2}\right)$; pakan dengan kandungan energi $65,00 \%$ dan protein $13,00 \%\left(\mathrm{P}_{3}\right)$; pakan dengan kandungan energi $65,00 \%$ dan protein $15,00 \%\left(\mathrm{P}_{4}\right)$; pakan dengan kandungan energi $70,00 \%$ dan protein $13,00 \%\left(\mathrm{P}_{5}\right)$; pakan dengan kandungan energi 70,00\% dan protein $15,00\left(\mathrm{P}_{6}\right)$. Adapun susunan dan kandungan nutrisi konsentrat tiap perlakuan tertera pada Tabel 1.

\section{Peralatan}

Peralatan yang digunakan dalam penelitian ini adalah:

1. Timbangan kapasitas $10 \mathrm{~kg}$ dengan ketelitian 20 gram untuk menimbang bahan pakan sebelum pencampuran konsentrat

2. Timbangan duduk kapasitas $2 \mathrm{~kg}$ dengan keteliatian 10 gram untuk menimbang konsentrat yang diberikan pada ternak serta sisa konsentrat yang tidak dimakan

3. Ember kecil untuk tempat minum ternak 
4. Meteran kain dengan panjang 1 meter untuk mengukur lingkar dada, panjang badan, panjang tanduk dan lingkar skrotum.

Tabel 1. Susunan ransum perlakuan dan komposisi nutrisi

\begin{tabular}{lcccccc}
\hline \hline \multirow{2}{*}{ Uraian } & \multicolumn{5}{c}{ Perlakuan } \\
\cline { 2 - 7 } & $\mathrm{P}_{1}$ & $\mathrm{P}_{2}$ & $\mathrm{P}_{3}$ & $\mathrm{P}_{4}$ & $\mathrm{P}_{5}$ & $\mathrm{P}_{6}$ \\
\hline Bahan ransum (\%) & & & & & & \\
Indigofera & 30,00 & 30,00 & 30,00 & 27,00 & 20,00 & 20,00 \\
Pelepah sawit & 5,00 & 5,00 & 5,00 & 4,00 & 3,00 & 3,00 \\
Bungkil inti sawit & 20,00 & 25,50 & 15,00 & 19,00 & 6,50 & 6,50 \\
Solid & 21,00 & 20,00 & 12,00 & 15,00 & 5,00 & 5,00 \\
Bungkil kedelai & 2,00 & 3,00 & 4,00 & 5,00 & 8,00 & 11,00 \\
DDGS & 4,00 & 7,00 & 7,00 & 10,00 & 12,00 & 14,00 \\
Onggok & 12,00 & 3,50 & 23,00 & 15,00 & 20,50 & 17,50 \\
Gaplek & & & & 21,00 & 18,00 \\
Molases & 5,00 & 5,00 & 3,00 & 4,00 & 3,00 & 4,00 \\
Ultra mineral & 0,30 & 0,30 & 0,30 & 0,30 & 0,30 & 0,30 \\
Tepung kerang & 0,50 & 0,50 & 0,50 & 0,50 & 0,50 & 0,50 \\
Garam & 0,20 & 0,20 & 0,20 & 0,20 & 0,20 & 0,20 \\
Jumlah & 100,00 & 100,00 & 100,00 & 100,00 & 100,00 & 100,00 \\
Komponen nutrien $(\%)$ & & & & & & \\
Bahan kering & 92,14 & 92,11 & 92,50 & 92,23 & 92,78 & 92,76 \\
Protein kasar & 13,00 & 15,00 & 13,00 & 15,00 & 13,00 & 15,00 \\
Lemak kasar & 7,10 & 7,71 & 5,90 & 6,64 & 4,06 & 4,14 \\
Serat kasar & 22,88 & 22,57 & 22,40 & 21,39 & 16,26 & 15,90 \\
TDN & 63,10 & 62,69 & 65,00 & 65,00 & 70,00 & 70,00 \\
\hline
\end{tabular}

Peubah yang diamati

\section{Indeks ukuran tubuh (IUT)}

Indeks ukuran tubuh (IUT) merupakan perbandingan antara panjang badan dan lingkar dada (Khargaria et al. 2015). Kisaran nilai IUT dapat mencerminkan kondisi ternak: gemuk $(0,94-1,04)$, sedang $(0,83-0,93)$ dan $(0,74-0,83)$. Pengukuran lingkar dada dan panjang tanduk mengacu kepada Fajemilehin \& Saloko (2008) yang menyatakan bahwa lingkar dada diukur dengan melingkarkan pita ukur pada dada tepatnya di belakang kaki depan sedangkan panjang badan diukur dari tonjolan tulang duduk dekat ekor sampai tonjolan pundak (occipital protuberance) dengan posisi kaki ternak lurus. 


\section{Lingkar skrotum}

Lingkar skrotum merupakan lingkar tengah kedua testis yang ada di dalam skrotum. Lingkar skrotum diukur dengan cara memijat testis ke arah bagian luar kemudian pita ukur dilingkarkan pada bagian skrotum yang memiliki lingkaran paling luas (Pezzanite et al. 2004).

\section{Panjang tanduk}

Tanduk merupakan keratin dan protein yang menggulung tulang di dalamnya yang tumbuh pada bagian kepala ternak. Panjang tanduk diukur dari pangkal sampai ujung tanduk mengikuti arah tumbuhnya menggunakan pita ukur (Otsuka et al. 1982).

\section{Rancangan penelitian dan analisis data}

Penelitian menggunakan Rancangan Acak Lengkap (RAL) dengan enam perlakuan. Masing-masing perlakuan diulangi sebanyak enam kali. Data ukuran lingkar dada, panjang badan, lingkar skrotum dan panjang tanduk dianalisis dengan analysis of varian (ANOVA) satu arah kemudian dilanjutkan dengan uji jarak berganda Duncan jika terdapat perbedaan (Steel \& Torrie 1990). Pengujian korelasi IUT terhadap lingkar skrotum dan panjang tanduk menggunakan analisis korelasi dengan program SPSS versi 16.0 .

\section{HASIL DAN PEMBAHASAN}

\section{Pengaruh perlakuan pakan terhadap ukuran lingkar dada, panjang badan, lingkar skrotum dan panjang tanduk}

Rataan pengaruh perlakuan pakan dengan imbangan energi dan protein yang berbeda terhadap parameter terukur pada kambing boerka jantan fase pertumbuhan disajikan pada Tabel 2.

Tabel 2. Pengaruh perlakuan pakan dengan imbangan energi-protein yang berbeda terhadap lingkar dada, panjang badan, lingkar skrotum dan panjang tanduk

\begin{tabular}{lccccccc}
\hline \hline \multirow{2}{*}{ Peubah yang diamati } & \multicolumn{7}{c}{ Perlakuan } \\
\cline { 2 - 7 } & $\mathrm{P}_{1}$ & $\mathrm{P}_{2}$ & $\mathrm{P}_{3}$ & $\mathrm{P}_{4}$ & $\mathrm{P}_{5}$ & $\mathrm{P}_{6}$ & Sig. \\
\hline Lingkar dada (cm) & 70,67 & 72,2 & 72,5 & 72,5 & 73,17 & 72,83 & 0,74 \\
Panjang badan (cm) & $72,31^{\mathrm{b}}$ & $72,59^{\mathrm{b}}$ & $56,17^{\mathrm{a}}$ & $55,50^{\mathrm{a}}$ & $67,09^{\mathrm{b}}$ & $57,83^{\mathrm{a}}$ & 0,01 \\
Lingkar skrotum (cm) & 24,17 & 26,4 & 23,5 & 24,5 & 24,67 & 24,33 & 0,9 \\
Panjang tanduk (cm) & 18,33 & 19,8 & 19,83 & 21,83 & 18 & 20,5 & 0,95 \\
Indeks ukuran tubuh & 1,01 & 1,03 & 0,80 & 0,79 & 0,93 & 0,79 & 0,99 \\
\hline
\end{tabular}

Superscript huruf yang berbeda pada baris yang sama menunjukkan perbedaan yang nyata $(\mathrm{P}<0,05)$

Hasil penelitian menunjukkan bahwa pengaruh pakan tidak berbeda nyata $(\mathrm{P}>0,05)$ terhadap lingkar dada. Rataan lingkar dada kambing boerka semua perlakuan lebih besar 
daripada kambing kacang dewasa yaitu 67,6 cm (Batubara et al. 2006) tetapi lebih kecil dari lingkar dada kambing PE yaitu 75,51 cm (Sodiq 2009). Ukuran lingkar dada kambing boerka dalam penelitian ini lebih besar daripada pejantan boer Indonesia umur 1 tahun Grade 1 yaitu 68,8 cm (Suryani 2016). Lingkar dada kambing Boerka dalam penelitian memiliki ukuran yang hampir sama dengan kambing Boer jantan umur 8-9 bulan yang dilakukan oleh Keith et al. (2009) yaitu 75,3 $\pm 4,87 \mathrm{~cm}$. Menurut Purwanti et al. (2019) lingkar dada dipengaruhi oleh 2 aspek yaitu pertumbuhan ukuran tulang rusuk dada dan pertumbuhan jaringan otot. Imbangan energi-protein dalam penelitian ini tidak memberikan pengaruh signifikan terhadap kedua aspek tersebut.

Perlakuan pakan memberikan pengaruh yang berbeda nyata $(\mathrm{P}<0,05)$ terhadap panjang badan. Perlakuan $\mathrm{P}_{1}$ dan $\mathrm{P}_{2}$ dengan energi $62,69 \%$ dan protein $15 \%$ merupakan panjang badan tertinggi yaitu mencapai 72,31 dan 72,59 $\mathrm{cm}$ hampir sama dengan rataan kambing Boer yaitu 64,6 $\pm 6,2 \mathrm{~cm}$ (Keith et al. 2009). Hal ini sesuai dengan hasil penelitian Syawal (2010) yang menyatakan bahwa performans kambing Boerka memiliki sifat kuantitatif lebih besar daripada kambing kacang tetapi lebih kecil daripada performans kambing Boer. Berdasarkan rumus, panjang badan berkorelasi positif dengan IUT. Semakin panjang ukuran badan, maka semakin besar pula nilai IUT atau dengan kata lain ternak semakin gemuk.

Perlakuan pemberian pakan pada penelitian ini tidak menunjukkan pengaruh yang nyata $(\mathrm{P}>0,05)$ terhadap ukuran lingkar skrotum. Rataan lingkar skrotum kambing Boerka yang diperoleh adalah 24,60 $\pm 0,97 \mathrm{~cm}$ hampir sama dengan kambing Boer yaitu $26,4 \pm 2,59 \mathrm{~cm}$ (Keith et al. 2009). Hal ini sejalan pula dengan penelitian yang dilakukan oleh Yustendi et al. (2013) yang menyatakan bahwa pemberian ransum tidak memberikan pengaruh yang nyata terhadap lingkar skrotum. Lebih lanjut dikemukakan untuk melihat pertambahan lingkar skrotum yang nyata dapat diberikan bahan aditif dalam ransum dengan imbangan energi-protein yang lebih tinggi berturut-turut yaitu $78 \%$ dan $18 \%$.

Hasil analisis variansi perlakuan pakan tidak menunjukkan pengaruh yang nyata $(\mathrm{P}>0,05)$ terhadap panjang tanduk. Namun, secara numerik, perlakuan $\mathrm{P}_{4}$ menunjukkan nilai u 21,83 cm. Rataan panjang tanduk kambing Boerka pada penelitian adalah 19,72 $\mathrm{cm}$ lebih besar 2 kali panjang tanduk kambing kacang dewasa yang hanya 7,8 $\mathrm{cm}$ dan juga lebih panjang dari kambing jantan dewasa Peranakan Ettawa yaitu $15 \mathrm{~cm}$ (Batubara et al. 2006).

Pemberian perlakuan pakan tidak memberikan pengaruh yang nyata $(\mathrm{P}>0,05)$ terhadap nilai IUT. Hasil hitung IUT menunjukkan perlakuan pakan $\mathrm{P}_{1}$ dan $\mathrm{P}_{2}$ menghasilkan kambing kategori gemuk, perlakuan pakan $\mathrm{P}_{5}$ menghasilkan kambing kategori sedang dan pakan perlakuan $\mathrm{P}_{3}, \mathrm{P}_{4}$ dan $\mathrm{P}_{6}$ menghasilkan kambing kategori kurus. Pakan perlakuan $\mathrm{P}_{2}$ menghasilkan nilai IUT dan mendekati nilai IUT tertinggi yaitu 1,03. Hal ini sesuai dengan penelitian yang dilakukan oleh Mathius et al. (2002) terhadap kambing PE yang menyatakan bahwa respon tertinggi penampilan ternak diperoleh pada pakan dengan taraf energi rendah dan protein tinggi dan berlaku sebaliknya.

\section{Korelasi IUT dengan lingkar skrotum dan panjang tanduk}

Korelasi antara IUT, lingkar skrotum dan panjang tanduk disajikan pada Tabel 3. 
Tabel 3. Korelasi IUT, lingkar skrotum dan panjang tanduk

\begin{tabular}{llll}
\hline \hline Uraian & IUT & Lingkar Skrotum & Panjang Tanduk \\
\hline IUT & & 0,619 & $-0,657$ \\
Lingkar Skrotum & 0,619 & & 0,011 \\
Panjang Tanduk & $-0,657$ & 0,011 & \\
\hline
\end{tabular}

Berdasarkan Tabel 3, terdapat korelasi antara lingkar skrotum dan IUT dengan nilai 0,619. Angka tersebut menunjukkan kuatnya korelasi antara lingkar skrotum dan IUT. Secara numerik, lingkar skrotum perlakuan $\mathrm{P}_{2}$ mencapai nilai paling besar yang sebanding dengan nilai IUT perlakuan tersebut. Hal ini sejalan dengan penelitian Hastono \& Arifin (2006) yang menyatakan bahwa lingkar skrotum domba Garut sebanding dengan bobot badan. Semakin besar bobot badan maka semakin besar pula lingkar skrotumnya.

Korelasi antara panjang tanduk dan Indeks Ukuran Ternak (IUT) bernilai -0,657 yang menunjukkan bahwa korelasinya sangat lemah atau dapat dikatakan tidak ada hubungan antara panjang tanduk dan IUT. Demikian juga korelasi antara panjang tanduk dan lingkar skrotum bernilai 0.011 yang menunjukkan korelasinya lemah. Tidak menunjukkan korelasi antara panjang tanduk dengan IUT dan lingkar skrotum dalam penelitian ini dimungkinkan karena tanduk masih tumbuh secara optimal seiring dengan umur ternak yang masih di bawah 1 tahun sebagaimana hasil penelitian Steeve at al. (1998) yang melakukan penelitian pada kambing Gunung (Oreamnus americanus) dan menyatakan bahwa ukuran tanduk masih tumbuh optimal sampai ternak berumur 1,5 tahun, menurun $93 \%$ pada umur 3 tahun dan tidak akan tumbuh signifikan pada umur 5 tahun.

\section{KESIMPULAN}

Pemberian pakan dengan imbangan energi - protein berbeda memberikan pengaruh yang nyata terhadap panjang badan tetapi tidak memberikan pengaruh yang nyata terhadap lingkar dada, lingkar skrotum dan panjang tanduk. IUT terbaik diperoleh pada pemberian pakan dengan imbangan energi $62,69 \%$ dan protein $15 \%$ dengan nilai 1,03 . Nilai IUT berkorelasi dengan lingkar skrotum tetapi tidak terdapat korelasi dengan panjang tanduk.

\section{DAFTAR PUSTAKA}

Batubara A, Doloksaribu M, Tiesnamurti B. 2006. Potensi keragaman sumberdaya genetik kambing lokal Indonesia. Prosiding Lokakarya Nasional Pengelolaan dan Perlindungan Sumberdaya Genetik di Indonesia. hlm. 206-214.

Bintara S. 2009. Peningkatan kinerja reproduksi induk kambing bligon melalui seleksi pejantan, identifikasi dan separasi spermatozoa, serta suplementasi energi-protein [Disertasi]. [Yogyakarta (Indonesia)]: Universitas Gadjah Mada.

Bourdon RM, Brinks JS. 1986. Scrotal circumference in yearling hereford bulls: Adjustment factors, heritabilities and genetic, environmental and phenotypic relationships with growth traits. J Anim Sci. 62:958-967. 
Fajemilehin OKS, Saloko E. 2008. Body measurement characteristic of the West African Dwarf (WAD) goat in deciduous forest zone of Southwestern Nigeria. Afr J Biothecnol. 7:2521-2526.

Hastono, Arifin J. 2006. Pengaruh lingkar skrotum terhadap kandungan testoteron, volume semen dan konsentrasi sperma domba garut. Prosiding Seminar Nasional Teknologi Peternakan dan Veteriner. Bogor (Indonesia): Pusat Penelitian dan Pengembangan Peternakan. hlm. 345-348.

Keith L, Okere C, Solaiman S, Tiller O. 2009. Accuracy of predicting body weight from body conformation and testicular morphometry in pubertal boer goats. J Anim Sci. 3:26-31.

Khaithoab RJ, Tegegneb A, Umunnaal NN, Nsahlaia V, Tammingab S, Bruchemb JV, Artsc JM. 1998. Effect of Leucaena and Sesbania siplementation on body growth and scrotal circumference of Ethiopian highland sheep and goats fed teff straw basal diet. Livest Prod Sci. 54:173-181.

Khargaria G, Kadirvel G, Kumar S, Doley S, Bharti PK, Das M. 2015. Principal component analysis of morphological traits of assam hill goat in eastern himalayan india. J Anim Plant Sci. 25:1251-1258.

Malan SW. 2000. The improved boer goat. Small Rumin Res. 36:165-170.

Mathius IW, Gaga IB, Sutama IK. 2002. Kebutuhan kambing pe jantan muda akan energi dan protein kasar: konsumsi, kecernaan, ketersediaan dan pemanfaatan nutrien. JITV. 7:99109.

Niam HUM, Agung P, Sularno D. 2012. Hubungan antara ukuran-ukuran tubuh dengan bobot badan sapi bali betina pada berbagai kelompok umur. Anim Agr J. 1:551-556.

Otsuka J, Namikawa T, Kozawa K, Mantojo H. 1982. Statistical analysis on body measurement of east asia native cattle. the origin and phylogeny of indonesia native livestock. Tokyo [Japan]: The Research Group of Overseas Scientific Survey.

Pezzanite L, Bridges A, Nearly M, Hutchens T. 2004. Breeding soundness examination of rams and bucks [Internet]. [cited 18 Juni 2019]. Available from: http://www.extension.purdue.edu/extmedia/AS/AS-599-W.pdf.

Purwanti D, Setiatin ET, Kurnianto E. 2019. Morfometrik tubuh kambing peranakan ettawa pada berbagai paritas di balai pembibitan dan budidaya ternak terpadu Kabupaten Kendal. J Ilmu-Ilmu Peternakan. 29:15-23.

Romjali P, Batubara A, Simanihuruk K, Elieser S. 2002. Keragaan anak hasil persilangan kacang dengan boer dan Peranakan Ettawah. Dalam: Hariyanto B, Setiadi B, Adjid RMA, Situmorang T, Prawiradiputra BR, Tarigan S, Wiyono A, Tresnawati MB, Murdiati TB, Abubakar, Ashari, Penyunting. Prosiding Seminar Nasional Peternakan dan Veteriner. Bogor (Indonesia): Pusat Penelitian dan Pengembangan Peternakan. hlm. 113-115.

Sodiq A. 2009. Karakterisasi sumberdaya kambing lokal khas kejobong di Kabupaten Purbalingga Provinsi Jawa Tengah. J Agripet. 9:31-37.

Syawal M. 2010. Karakteristik morfologi dan produksi kambing boer, kacang dan persilangannya pada umur 0-3 bulan (prasapih). Dalam: Prasetyo, et al., penyunting. Prosiding Seminar Nasional Teknologi Peternakan dan Veteriner. Bogor (Indonesia): Pusat Penelitian dan Pengembangan Peternakan. hlm. 616-620.

Steel RGD, Torrie JH. 1990. Principles and procedures of statistics. 2nd ed. Biometrical Approach. London (UK): McGrawhile International Book Co. 
Steeve SC, Marco FB, Kirby GS. 1998. Horn growth in mountain Goats (Oramnus americanus). J Mammal. 9:406-414.

Suryani AI. 2016. Perbedaan bobot badan dan ukuran tubuh kambing boerawa grade 1 umur satu tahun dari beberapa pejantan kambing boer di Kecamatan Sumberejo [Skripsi]. [Lampung (Indonesia)]: Universitas Lampung.

Yustendi D, Dasrul, Rachmadi D. 2013. Penambahan tepung daun katuk (Saurupus androgynus 1. merr) dalam ransum terhadap pertambahan bobot badan dan lingkar skrotum kambing jantan Peranakan Ettawa. Agripet. 13:7-14.

Zurahmah N, The E. 2011. Pendugaan bobot badan calon pejantan sapi bali menggunakan dimensi ukuran tubuh. Buletin Peternakan. 35:160-164. 